\title{
Remembering Zeami: The Kanze School and Its Patriarch
}

\author{
Eric C. Rath
}

\begin{abstract}
This article examines the history of the reception and popularization of the achievements of nō's founder, Zeami Motokiyo, as represented by three important actors of the Kanze school: Kanze Motoakira (d. 1774), Kanze Sakon (d. 1939), and Kanze Hisao (d. 1978). Eric Rath describes how memories of Zeami helped these three actors to shape the Kanze school's performance practices and institutions. He reveals, too, how debate over nō's direction and essence has come to be framed in respect to the person considered to be its patriarch.

Eric C. Rath is assistant professor of premodern Japanese history at the University of Kansas. He is the author of several articles on the history of nō and the forthcoming book The Ethos of Noh: Actors and Their Art (Harvard University Asia Center Press).
\end{abstract}

It is hard to imagine a history of $n \bar{o}$ that does not grant a central role to its greatest playwright and theorist, Zeami Motokiyo (d. 1443). As the noted actor Kanze Hisao exclaimed: “Today Zeami's theories about $n \bar{o}$ are available not just in Japan, but have been translated into many different languages, and they are read closely since they are recognized by people from around the world as important works on theatre" (Kanze Hisao 2001, 30). Yet before the rediscovery and publication of Zeami's secret writings in the first decade of the twentieth century, which inaugurated scholarly study of his life and work, popular understanding of his contributions was based more on what can be termed myth than historical fact. Even as late as the early 1940s, when the Kanze school published its official collection of plays, the Kanzery $\bar{u}$

Asian Theatre Journal, vol. 20, no. 2 (Fall 2003). (c) 2003 by University of Hawai'i Press. All rights reserved. 
Taiseiban Utaibon (Kanze School Complete Collection of Nō Plays), over half of the two hundred plays were attributed to Zeami (Kanze Hisao 2001, 48). Modern scholarship recognizes only twenty to thirty plays by Zeami and perhaps fifty more he had some hand in editing.

"Factual" understandings of Zeami's achievements have debunked many myths about Zeami. But are these modern renderings any less arbitrarily constructed than their premodern antecedents? The sociologist and scholar of memory Maurice Halbwachs has asserted that "the only ancestors transmitted and retained are those whose memory has become the object of a cult by men who remain at least fictitiously in contact with them" (Halbwachs 1992, 73). In the case of $n \bar{o}$, the memory of Zeami as an ancestor exists on two levels today: first, on the popular level, or what Halbwachs calls the "framework of social memory," as the "founder" of $n \bar{o}$ theatre, and, second, on a more personal level, as the patriarch of the Kanze family, the largest school of $n \bar{o}{ }^{1}$ When certain members of the Kanze family have invoked Zeami's name, they have done so on both of these levels, simultaneously eliciting a personal link with their great forefather and with the wider historical legacy of $n \bar{o}$ that Zeami is made to represent.

This article focuses on the views of three prominent descendants of Zeami: Kanze Motoakira (d. 1774), Kanze Sakon (d. 1939), and Kanze Hisao (d. 1978), all of whom drew prominence to their connections with Zeami in their stage work and writings. Motoakira and Sakon were the fifteenth- and twenty-fourth-generation leaders of the Kanze school; Hisao was from the prestigious Tetsunojō branch of the Kanze house that began with Motoakira's younger brother, Hattori Kiyonao (d. 1782). Motoakira, Sakon, and Hisao sought to define relationships with Zeami that were as much personalized views of his legacy as they were privileged claims to authority over $n \bar{o}$ 's traditions. These three different representations of Zeami are important, first, as examples of the use of memory, or what can also be called "invented tradition," to overcome moments of personal and institutional crisis and even to justify radical innovations in $n \bar{o}$. And second, since these pronouncements come from important figures in the $n \bar{o}$ world, they are significant contributions to the wider reception of the meaning of $n \bar{o}$ and Zeami's legacy.

\section{Zeami's Legacy from the Late Medieval to the Edo Period}

Before we take up specific interpretations of Zeami's life, the dominant premodern interpretations of his role in $n \bar{o}$ 's past deserve attention. Zeami's historical reception after his death was tempered by the knowledge that although he was recognized as one of the most 
important actors of the early days of $n \bar{o}$ in the fifteenth century, his popularity waned later in his life and he even suffered exile. Other performers, most notably Zeami's nephew On'ami (d. 1467), were recognized to have eclipsed his fame during his life, though modern scholars understand that the relationship between the two apparently was strained. One Edo-period (1600-1868) genealogist of the Kanze school erroneously explained the reason for Zeami's exile as punishment for turning against On'ami. ${ }^{2}$ When the Kanze troupe rediscovered a trove of Zeami's writings in the sixteenth century, a collection said to have belonged to Zeami's son Motomasa (d. 1433), they seem to have made little impact on the leaders of the Kanze school except as commodities for leveraging patronage ties with powerful warlords. The Kanze leader Sōsetsu (d. 1583) gave away copies and original versions of Zeami's secret writings to the warlords Hosokawa Yūsai (d. 1610) and Tokugawa Ieyasu (d. 1616). Zeami's treatises saw little dissemination beyond this point, and the ownership of Zeami manuscripts can be traced fairly accurately to the modern era as a result. More widely circulated $n \bar{o}$ treatises reveal that Kanze On'ami remained equal if not more important than Zeami up through the sixteenth and seventeenth centuries, as seen in the number of apocryphal secret writings ascribed to him, such as the Jikkansho (Writings on the True Mirror). Significantly On'ami, not Zeami, was represented as joint author of the influential mid-sixteenth-century no encyclopedia, the Hachijo Kadensho (Eight Volume Treatise on the Transmission of the Flower), although portions of Zeami's writings, not On'ami's, composed part of this work. In terms of the circulation and importance given latemedieval $n \bar{o}$ theories as well, Konparu Zenpō's (b. 1454) formulation of the five modes (go'on) had a far greater impact on aesthetic and dramaturgical thought in the sixteenth and seventeenth centuries than Zeami's theories, if only by virtue of the fact that Zenpō's ideas were much more widely disseminated (Rath 1999, 177).

Zeami's reputation rose in the Edo period thanks to the repeated publication of an erroneous theoretical writing called the Kadensho (Treatise on the Transmission of the Flower) that was falsely attributed to him. (It was in fact the Eight Volume Treatise on the Transmission of the Flower once ascribed to On'ami and others; Rath 1999, 169-170). Moreover, the great popularity of singing $n \bar{o}$ plays (utai), a fad fueled by the publication of no libretti, called utaibon, ensured Zeami's reputation in the Edo period as a playwright (Kano 1997, 155). Little, however, was known about the details of his life. The apocryphal stories circulating in the Edo period about Zeami were certainly less colorful than those told about other medieval actors, such as Hana 
(Nose) Kongō Sōsetsu (d. 1576), whose face once stuck to a mask, forcing him to rip off his nose, or Konparu Zenchiku (d. 1470?), who, according to the secret writings of the Konparu troupe leader Yasuteru (d. 1621), allegedly had a sexual encounter with the wild monk of Zen, Ikkyū (d. 1481) (Dōmoto 1992, 291).

Ever since Zeami himself mentioned the role of the ancient statesman Prince Shōtoku (d. 622) in the creation of nō in the Fūshikaden (Style and the Flower), the rhetorical summoning of the spirits of ancient patriarchs to assert legitimacy within the field of $n \bar{o}$ had long played a prominent role in $n \bar{o}$ 's construction of authority. Yet myths about "founders" received greater prominence in the Edo period with the efforts of both the Tokugawa military government (bakufu) and performers to transform $n \bar{o}$ into a hereditary profession. Proving hereditary links with ancient masters helped to sustain the dominance of the prominent $n \bar{o}$ families, while the premise that bloodlines formed the basis for expertise in $n \bar{o}$ served as a gatekeeping device for maintaining vocational boundaries. Thus when the Tokugawa military government in the Kyōhō era (1716-1735) demanded that the $n \bar{o}$ troupes in its employ submit descriptions of the history of $n \bar{o}$ and their genealogies, the Hōshō troupe presented a chronicle that accented the contributions of their founder, Hōshō Ren'ami (d. 1467?), while the Konparu troupe praised its ancestors Hada no Kōkatsu and Zenchiku rather than Zeami (Geinōshi Kenkyūkai 1978, 225-226). Even the Kanze troupe in the same report divided the invention of $n \bar{o}$ among its first three generations of leaders, namely the "dramatist" Kan'ami (d. 1384), the "playwright" Zeami, and the "actor" On'ami (Geinōshi Kenkyūkai 1978, 215).

\section{Kanze Motoakira: Consolidating Tradition}

Kanze Motoakira's scholarship on Zeami confirmed the accepted view that Zeami's fame was gained as a playwright. But his approach marked a significant departure from earlier discussions of Zeami both in its scholarly caliber and in its appreciation of Zeami as a living, historical figure rather than a legend. Motoakira evoked Zeami as the consummate image of a troupe leader whom he himself strove to become-someone who had mastery over the highest secrets of the art and what can be termed "exoteric" techniques displayed in performances. Motoakira had the fortune and political savvy to employ this image of leadership as a means to consolidate his control over his acting troupe as no other Kanze leader had done before. ${ }^{3}$

What differentiated Motoakira from previous troupe leaders, who used Zeami's secret writings in the trade of prestige for arcane knowledge, was the special respect that he gave these texts. He not only 
disseminated Zeami's treatises, but he also added copious notes, revealing his training in philology, which he gained from study with national learning (kokugaku) scholars such as Tayasu Munetake (d. 1771). Motoakira added notations to Zeami's Shikadō (True Path to the Flower), Nikyoku Santai Ningyō Zue (Illustrations for the Two Basic Arts and Three Role Types), Shüdossho (Learning the Way), and Style and the Flower. He then selectively disseminated these texts to close disciples.

One of the first texts Motoakira allowed to selectively circulate was Learning the Way, a treatise arguing that the leader of the troupe possessed the most skill and authority (Ejima 1977). Motoakira later published this text for a general audience in 1772. Toward the end of his life he prepared a version of Style and the Flower with the same aim in mind, but he died before its publication. Amid the long-standing practice of venerating secret writings solely on the basis of their secrecy - and against the general preference in the Edo period for texts detailing performance techniques (katazuke)-Motoakira's scholarly efforts marked an important step in identifying and explicating Zeami's theoretical ideals. ${ }^{4}$ He prepared these annotations of Zeami's treatises for top disciples and the public, not simply to promote Zeami, but to ensure that his own authority as Zeami's annotator and descendant should be acknowledged. This was essential if Motoakira was to realize his plans to standardize the performance practices of the Kanze school. Sakon worked hard to popularize Kanze-school $n \bar{o}$ in the Edo period as seen in his revival of large, outdoor "subscription" (kanjin) performances. His fifteen-day subscription performance in Edo in 1750 , the first such show in a century, featured the subscription debut of the important play Shakkyō (Stone Bridge). Sixty years later Sasaki Haruyuki, the author of Su'utai Yoyo no Ato (Traces of Unaccompanied Nō Chant Through the Ages), described this event as a seminal moment in the history of $n \bar{o}$ (Sasaki 1978, 674-675). Motoakira was also keen to use the medium of print to reach a wider audience and refine his role as a $n \bar{o}$ expert. As mentioned earlier, he published Zeami's Learning the Way in 1772. He also published Fukugenkan (Volume of Supplemental Words), a collection of scripts to the kyogen interludes (aikyōgen) found in most $n \bar{o}$ plays.

Motoakira's most significant step in using print to claim authority was his revision of the Kanze school's texts of $n \bar{o}$ plays. Thanks to amateur interest in singing $n \bar{o}$ plays and to their occasional use as textbooks in temple schools (terakoya), utaibon were best-selling books in the Edo period, and most were written with the performance notations in the style of the Kanze school. Unlike today when the head of the Kanze school controls the right to publish $n \bar{o}$ plays written in the style of performance of the Kanze school, in the Edo period anyone with a 
press could print Kanze utaibon. This meant that the preceding leaders of the Kanze troupe who published their own utaibon had to compete with many other authors who produced works of varying quality. These leaders also had to defend their versions of Kanze-school texts against others, which left the public with a muddied perception of the Kanze style and indeed the authority of the troupe leader in determining it.

Consequently, Motoakira's decision to issue his own revised collection of utaibon, titled the Meiwa Kansei Utaibon (Revised Utaibon of the Meiwa Period), one that would contain authoritative versions of $n \bar{o}$ plays, marked his effort not only to corner a lucrative market but also to define once and for all the authoritative Kanze style. He undertook this project with financial backing from the bakufu, which provided him with several loans and the use of its official print shop, one that had never printed $n \bar{o}$ texts before. The fact that his teacher, Tayasu Munetake, assisted in the project and was the second son of the eighth shogun, Tokugawa Yoshimune (d. 1751), certainly helped Motoakira in winning the bakufu's support. He also enlisted the assistance of the most prominent scholars of his day, including the poet Katō Enao (d. 1785) and the noted philologist Kamo no Mabuchi (d. 1769), expert in the eighth-century Manyōsh $\bar{u}$ (Collection of a Myriad Leaves). Motoakira's research team endeavored to correct the wording of $n \bar{o}$ plays by reconciling them with the poems and literary works that were their sources. His scholars made these corrections in red ink and wrote notations for all of the 210 plays in the final collection.

These changes went beyond simple corrections in the texts. Motoakira sought to delineate how the plays were to be performed by specifying costuming, the use of props, and stage directions. He even specified the correct pronunciations for certain words. Prior to this time, $n \bar{o}$ actors relied on their personal preferences, family customs, and various oral and written traditions to produce plays. Motoakira sought to standardize these for the Kanze school, frequently creating new performance practices for plays in the process. For Zeami's play Tadanori, for example, Motoakira specified that a representation (tsukurimono) of a cherry tree be placed on stage although one had not been used before. He also modified the props used in the same play, replacing a tanzaku (a rectangular poem card) with an open fan. In the Heike Monogatari (Tale of Heike), Zeami's source for this play, a poem card was used to identify Tadanori's body after he was slain. Motoakira's replacement of it with a fan made the reference to the card less representational. This move toward abstraction was heightened by the fact that Motoakira directed the actor to remain seated the entire time as he read the poem and described his death whereas previously the actor once turned while standing in performing the same passage (Oda 1990, 106-107). 
Motoakira invoked Zeami's name to add legitimacy to these often arbitrary changes by prefacing his play collection with Zeami's call to his descendants to revise the text of $n \bar{o}$ plays. Motoakira had cited the same passage in a previous work, a list of the authors of 210 plays, the Nihyakujūban Utai Mokuroku (Catalog of 210 Nō), which he published in 1765. There he identified Zeami's treatise Nōsakusho, (Composing Nō Plays; also called the Three Elements in Composing Nō

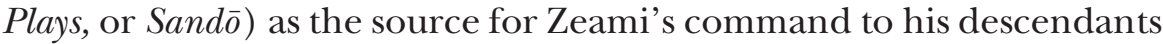
to correct the errors in $n \bar{o}$ plays (Nishio 1977, 157-158). With this step Motoakira positioned himself as fulfilling his ancestor's ancient wish, even though Zeami's text never made such a plea.

Zeami's fame increased due to Motoakira's project. Though Zeami already was recognized as a great playwright in the Edo period, Motoakira further enhanced Zeami's standing in this regard in his revised $n \bar{o}$ texts by identifying seventy-three plays Zeami had written. As noted earlier, this calculation was more than twice as many plays as Zeami is believed to have composed. Motoakira also revived plays by Zeami for inclusion in his revised play collection that were no longer performed such as Akoya no Matsu (The Pine of Akoya), Furu, and Matsu'ura no Kagami (The Mirror of Matsu'ura). ${ }^{5}$ By documenting Zeami's great impact on the Kanze school's repertoire, Motoakira further strengthened his own authority as Zeami's filial descendant-and hence more able than anyone else to comment on his ancestor's legacy.

Motoakira may not have needed to have given so much attention to Zeami had his publication of this collection of $n \bar{o}$ plays not amounted to a revision of these works that marked a significant restructuring of the Kanze troupe's repertoire and style. Since Motoakira mandated that Kanze-school performers purchase and use only his utaibon, he challenged professional teachers of utai in the Kanze school who drew upon a much wider range of texts and preserved their own distinct styles of performing these works. According to the bakufu official and poet Kanzawa Tokō (d. 1795), these teachers criticized Motoakira. Kanzawa described the complaints against Motoakira's canonization of plays, especially its omission of $n \bar{o}$ popular in Kyoto, where Kanzawa lived (Kanzawa 1978, 15-49). Kanzawa further noted the idiosyncratic nature of Motoakira's play collection as exemplified by his inclusion of the play Ume (Plum Blossom), which Motoakira himself had written. Motoakira defended this play in his Catalog of 210 Nō Plays, stating that it had been created as an example of how to write $n \bar{o}$ following the models of ancient precedent set by Zeami-implying that recent authors of $n \bar{o}$ had forgotten these time-honored rules for composition (Nishio 1977, 158). This conflict reveals that Motoakira saw his mandate as Zeami's descendant to set standards of nō performance that would be uniform throughout Japan for all members of the Kanze 
school, regardless of the existence of local texts and performance practices that people like Kanzawa favored.

Besides the restrictions on performance practices and the repertoire, after the publication of the Meiwa text no performers had to cope with Motoakira's attempt to define and standardize performance variations, called kogaki, for nō plays. Kogaki are departures from standard performances that help to demarcate a play's level of dignity (kurai). As Yamanaka Reiko has noted, variations can assist actors in drawing the audience's attention to the high points of certain plays or in giving a distinct interpretation to a role (Yamanaka 1997, 148). Motoakira's Meiwa Kansei Utaibon included 250 kogaki in ninety-four plays with an average of one to three per play, many of which were his own invention or were at least named by him. In light of Yamanaka Reiko's comments, Motoakira's interest in codifying the variations to plays by Zeami and other authors can be seen as analogous to his exegesis of Zeami's treatises. In both cases, Motoakira highlighted parts that he deemed important and asserted his authority to make such interpretations. The latter point is especially evident in his delimitation of the number of kogaki and decision to name them all, thereby rationalizing his control over their use.

Kogaki came to require the troupe leader's permission because of their association with secret teachings called narai, the important esoteric teachings needed to perform difficult or spiritually elevated aspects of nō plays. No teachers had begun issuing licenses for narai since at least the seventeenth century, but Motoakira's systematization of kogaki and narai created a hierarchy that culminated in ten special narai plays (Naraimono), eight of which Motoakira attributed to Zeami and all of which necessitated the troupe leader's permission to perform.$^{6}$ In creating this codification of narai, Motoakira also increased their number. The scholar Oda Sachiko estimates that there were only about forty narai in the generation of Motoakira's father, but by the time of Motoakira's death the number of narai in the Kanze school had increased to 230-most of which Motoakira himself had created (Oda 1990, 105). These innovations formed the foundation for the modern amateur licensing system in $n \bar{o}$, which ranks plays, kogaki, and narai according to level of difficulty and dignity and demands appropriate fees for amateurs to obtain them. Though many performers contributed to the development of this licensing system, secret knowledge had a much more codified and prominent place in the Kanze school thanks to Motoakira.

Kanze Motoakira invested his personal authority in the project to revise his school's repertoire of plays, and this achievement was viewed as synonymous with him during his lifetime because publication of the collection ended just three months after his death. Nevertheless, 
his institutional changes endured. Nō scholars today consider Motoakira to be one of the first family heads (iemoto) in $n \bar{o}$ in light of his achievements (Nakamura 1967, 24). It is significant to note that a more concrete figure of Zeami as a playwright and as a theorist emerged at the same time that $n \bar{o}$ 's performance practices, repertoire, and familyhead system crystallized.

\section{Kanze Sakon: Invoking Tradition}

Motoakira turned esoteric traditions into public commodities by his prototypical hierarchy of secret teachings and publication of a few of Zeami writings. The next leader of the Kanze to be as conspicuous in this regard was Kanze Sakon. Sakon was a self-acknowledged admirer of Motoakira and a student of Zeami's secret treatises. Zeami's legacy served as a means for Sakon to present himself as a fully sanctioned family head just as his ancestor Motoakira had.

Sakon's interest in Zeami's secret texts can be traced to his early life experience and training. He was born in the Katayama house in Kyoto, where his father, Kanze Hisashi, the third son of the twentysecond head of the Kanze family, had been adopted as heir. Sakon was somewhat of a prodigy, dancing the difficult Stone Bridge at the precocious age of nine (Numa 1953, 62). When Sakon's uncle, Kanze Kiyokado, the twenty-third head of the Kanze family, needed an heir, however, Sakon was adopted into the Kanze house at thirteen. Four years later Kiyokado died, leaving Sakon without a teacher and role model. Other teachers, including his father, helped educate Sakon, but he later reported in his memoirs that the secret writings of Zeami proved his greatest teacher.

Another reason for Sakon to embrace Zeami's secret writings publicly was to confront the problem of their wider availability. In 1909 more than a dozen of Zeami's treatises had been rediscovered and published, and Sakon had to begin to reconcile the knowledge revealed in these texts with other Kanze traditions such as discrepancies in the date of death of Zeami's father, Kan'ami (Kanze Sakon 1939, 58). But publication of another collection of secret writings may have posed an even greater challenge to Sakon's authority. Kinoshita Keiken's (d. 1916) Nōgaku Un'nōsh ū (Collection of Esoteric Teachings on Nō Theatre) saw publication five years before Sakon's birth, but its revelation of secret narai prompted Sakon's predecessor, Kiyokado, to disbar the author from the Kanze school. This text can be seen as a personal challenge to Sakon since it contained secret teachings belonging to the Katayama house of Sakon's birth. Sakon publicly denounced the work declaring that it did not represent the pure teachings of the Kanze school, which he devoted his career to standardizing (Kanze Sakon 1939, 141).

Sakon was further sensitized to the issue of stylistic uniformity 
by internal divisions within the Kanze school over the attempt of the prominent Umewaka family to leave and form their own school of $n \bar{o}$. This well-known struggle began in the Meiji period (1868-1912) over the right of the Umewaka house to issue licenses independently of the leader of the Kanze. At first Sakon advocated that the Umewaka should be allowed to break away from the Kanze. But when the other schools opposed the formation of a new Umewaka school, in 1921 Sakon was forced to ostracize the members of his school who supported this move including Umewaka Mansaburō (d. 1946), his younger brother Minoru II (d. 1959), and Kanze (Kasetsu) Tetsunojō VI (d. 1959), who had married Minoru's daughter and was a champion of their cause. The three actors and their supporters who created the new Umewaka school faced difficulty mounting performances since the newly formed $n \bar{o}$ professional association, Nōgaku Kyōkai, stood against them and musicians and actors of other schools refused to take the stage with them. In 1929 Tetsunojō VI returned to the Kanze and four years later Umewaka Mansaburō followed. With two of the leaders of the Umewaka school having returned to the Kanze, Sakon began the task of revising the school's utaibon to create more stylistic uniformity among the Kanze, the Tetsunojō house, and the Umewaka (Fujinami 1981, 141). The Umewaka problem, however, was not fully resolved until Minoru II's return to the Kanze in 1954.

Like Motoakira, Sakon wanted to use the publication of a new standardized repertoire of $n \bar{o}$ plays to foster stylistic uniformity, group cohesion, and professional obedience within the Kanze school. Following his great predecessor, Sakon invoked Zeami's name at the introduction of his own revised version of the Kanze school's utaibon, the Taiseiban Utaibon (Kanze Sakon 1995, i). The results can be viewed as an extension of the standardization of the Kanze school's style begun by Motoakira, who appears to have been a role model for Sakon. Indeed Sakon made specific mention of his admiration for Motoakira's Meiwa Kansei Utaibon in his memoirs, and in the same work he even annotated a text that Motoakira had written about masks. He also outdid his ancestor in praising Zeami's contribution, however. Where Motoakira had identified more than seventy plays by Zeami, Sakon claimed he had authored more than a hundred.

Sakon too gathered an impressive array of scholars for the utaibon project, which included the top nō scholars of the era: Nonomura Kaizō, Nogami Toyoichirō, Nose Asaji, Kobayashi Shizuo, and Miyake Noboru. Sakon's disciple and collaborator in his revision project, Fujinami Shisetsu, described its aim to amend the wordings of plays and provide clearer specifications about how they were to be performed (Fujinami 1981, 138). Sakon's team clearly designated the sound level 
(onkai) for sung passages, and they added notations designating pronunciation. He also ordered for the first time that all of the 210 plays fit into the now familiar five-category scheme for categorizing $n \bar{o}$ : god, warrior, woman, miscellaneous, and demon $n \bar{o}$.

Besides ameliorating differences among performance styles and factions within the Kanze school, the utaibon project assisted Sakon in gaining greater control over Kanze-school performers throughout Japan. In Kyoto, for instance, Kanze-school performers maintained their own local singing style. Sakon's father received a poor reception in Kyoto when he first arrived, and he resolved thereafter to make the Kyoto performers sing in the "standard" Tokyo style. According to the $n \bar{o}$ critic Numa So'u, Sakon succeeded in forcing the Kyoto actors to conform to these standards (Numa 1953, 66). The Kyoto style of Kanze $n \bar{o}$, along with other regional variations, has since disappeared in the wake of efforts to nationalize performance practices.

Sakon's project to revise the utaibon supported his other efforts to add dignity to the Kanze school by highlighting its traditions. In 1907 he resuscitated the ceremony of New Year's songs (utaizome), a program featuring the sung portions of a few auspicious plays. During the Edo period, leaders of the Kanze school had conducted this yearly rite for the Tokugawa shoguns. Sakon staged his revival at Tōshōgū Shrine in Tokyo, which honored the memory of the first Tokugawa shogun, Ieyasu. In his memoirs, Nōgaku Zuisō (Notes on Nō Theatre), Sakon presented historical documents describing this ceremony. In the same work he also cataloged all of his family's treasures, which included some masks mentioned in Zeami's writings (Kanze Sakon $1939,11-12)$. But it was these secret texts that were his family's greatest treasure, according to Sakon, for these were what gave him authority to act as leader of the Kanze school. He wrote: "I, Kanze Sakon, perform and interpret things as head of the Kanze school as a result of my research in numerous [secret] writings, which means I can speak with confidence in describing what constitutes the style of the Kanze school" (Kanze Sakon 1939, 82).

Although he himself was widely acknowledged as a great actor with expertise on Zeami and other ancient $n \bar{o}$ traditions, Sakon's memoirs are disappointingly vague about what he thought about the theoretical aspects of Zeami's work, which he tended to invoke in the same breath as other "ancient texts." Sakon's memoirs give the impression of someone who is more concerned with the technicalities of tradition than with using Zeami's ideas to define the meaning of $n \bar{o}$ as an art the way Kanze Hisao did. Nevertheless, since very few actors before World War II read Zeami in the original, Sakon's familiarity with the technical aspects of Zeami's Talks on Sarugaku and other treatises was remark- 
able in his effort to show the public how he linked these texts to performance practices.

\section{Kanze Hisao: Breaking Tradition}

Few actors today might read Zeami's treatises in the original as Motoakira and Sakon did, but they do read artistic memoirs by other performers to learn about Zeami secondhand. In this regard, the writings of Kanze Hisao are influential for introducing Zeami to the $n \bar{o}$ community. The $n \bar{o}$ scholar Omote Akira once described Hisao as the preeminent authority among performers on Zeami. Hisao also served an essential role in allowing scholars access to the secret writings of the Kanze school (Watanabe 1980, 55 and 97). Moreover, Hisao hoped that wider understanding of Zeami as a theorist would rejuvenate $n \bar{o}$ theatre in the latter half of the twentieth century.

Hisao was the first son of Kanze Gasetsu (d. 1988), who took the name Kanze Tetsunojō VII in 1947.7 As noted earlier, his uncle and chief teacher Kanze (Kasetsu) Tetsunojō VI was involved in the illfated Umewaka school and later in Sakon's project to revise the utaibon. This meant that Hisao made his stage debut at age four in the shortlived Umewaka school but later held an influential place in the Kanze family. Hisao entered maturity at the end of World War II at a moment when there were very few opportunities to perform, which meant that actors could concentrate on training. In the immediate postwar era, he studied with the great Hōshō-school actor Noguchi Kanesuke (d. 1953) as part of a training program for young actors begun in 1946. He later studied the acting methods of Stanislavsky and the Polish director Jerzy Grotowski and trained in France for six months with Jean-Louis Barrault.

In an interview published in 1972, Hisao explained why he took an interest in learning and performing other genres of theatre besides $n \bar{o}$. In response to the interviewer's question about his appearance in a 1971 production of Oedipus, Hisao commented: "For me, even if it's classical Greek drama that I am trying, I can learn something about $n \bar{o}$ by doing so; and since I perform $n \bar{o}$, I am also able to make discoveries when I perform classical Greek drama" (Kanze Hisao et al. 1972, 118). In performing $n \bar{o}$, Hisao sought to integrate his traditional training as a $n \bar{o}$ performer with his interest in Western methods, as he commented in a different interview in 1971: "When I play a kyojo [mad woman] in a Noh play. . . -having read Zeami, on the one hand, and having learned Stanislavski's theory, on the other-I think I might learn what the reality of acting is, especially as a modern actor" (Harris 1973, 323).

Despite his interest in a wide range of types of theatre, Hisao 
insisted that his encounter at a young age with Zeami's writings was what provoked him to try to rediscover the essence of $n \bar{o}$ and attempt to reform it (Kanze Hisao 1984, 142). Hisao's first formal introduction to Zeami's treatises occurred in the scholar Nose Asaji's university lectures, which Hisao attended regularly from 1949 to 1950. In 1950, Hisao joined a $n \bar{o}$ ensemble called the Renaissance Group, which he hoped would put Zeami's ideas into theatrical practice. Ironically, some outsiders thought that the "rebirth" suggested by the group's name referred to revolution, not to Zeami's ideas, and the Suidōbashi theatre where they performed was often the target of anticommunist graffiti (Harris 1973, 23). Instead of a struggle against capitalism, Hisao's objective was to revive Zeami's ideas, lost to feudalistic tendencies in the Edo period. He explained his belief that $n \bar{o}$ actors stopped reading Zeami in the Edo period when $n \bar{o}$ became a ceremonial theatre (shikigaku) catering to the shoguns (Kanze Hisao 1984, 56-61). He urged modern actors to return to Zeami's ideas and clarified their importance:

To perform no today, more than anything else it is necessary to break away from the ideas of ceremonial performances for warriors and shine light on the time of Zeami. This does not mean turning back the clock five hundred years and returning to the Muromachi period. What it means is returning to the power of Kan'ami and Zeami that was coursing through society five hundred years ago and taking that energy and returning it to $n \bar{o}$. [Kanze Hisao 2001, 26-27]

To clarify the meaning of Zeami's theories and actualize them onstage, the Renaissance Group created a Zeami study group, Zeami Densho Kenkyūkai (Research Group on Zeami's Treatises), in 1952. This group read Zeami's writings with the preeminent no scholars of the age, including Nishio Minoru, Kon'ishi Jin'ichi, Yokomichi Mario, and Omote Akira. Years later Hisao reflected that this experience taught him the definition of $n \bar{o}$ and how to live as an actor (Kanze Hisao 1984, 238).

Hisao's manner of reading Zeami's treatises marked a radical departure from the way his predecessors approached these texts. Whereas Motoakira and Sakon had worked from fragmented copies of original manuscripts, Hisao read modern annotated collections of Zeami's writings alongside the same scholars who were editing them for publication. Hisao's approach is further characterized by his dictum that Zeami's art must be understood in terms of Zeami's biography. For example, he dated Zeami's creation of the aesthetics of dream (mūgen) nō such as Izutsu (The Well) and Nonomiya to the latter part of his life, arguing that Zeami developed a more abstract drama empha- 
sizing music and dance in his later years (Kanze Hisao 1984, 64 and 133-136). Hisao formulated this idea late in his own career at a time when he sought to perform Western drama, classical Greek tragedies, and the plays of Samuel Beckett according to a sense of abstract artistry that some critics found wanting. Yokomichi Mario, for instance, faulted Hisao's 1973 performance of Beckett's Waiting for Godot (Godō o Machinagara). Yokomichi noted that the play looked like a rehearsalperhaps indicative of Hisao's dislike of appearing onstage without a mask - and he found an incongruity in $n \bar{o}$ performers delivering lines like actors in a modern drama, departing from their customary style of declamation used in $n \bar{o}$ (Yokomichi and Kobayashi 1996, 80-81).

Hisao's greatest contribution to research on Zeami, according to Omote Akira, was in his understanding of Zeami's life. Omote explains that Hisao not only read about Zeami but also attempted to live as Zeami would have lived (Watanabe 1980, 76). The story of Hisao's first performance experience with a $n \bar{o}$ mask illustrates his close sense of connection with Zeami at an early age. He wrote how the first mask he ever wore was an ancient demon mask that conceivably Zeami himself could have worn. Hisao described his deep sense of awe and responsibility when he realized this (Kanze Hisao 1981, 285). As Omote explains, Hisao's efforts to live like Zeami inevitably brought him into conflict with $n \bar{o}$ as an institutional system. In 1965, Hisao rejected a government award as an Intangible Cultural Asset in protest against government sponsorship of the arts and the family-head system. In a more constructive move, Hisao helped found the Hana no Kai (Flower Group) in 1953, which was inspired by Zeami's theories, and the Zeami-za (Zeami Troupe), a nō group that toured Europe in 1972 and 1976.

Hisao's interpretation of Zeami stood opposed to the institutional renderings of Zeami that earlier Kanze leaders had helped create. For Hisao, Zeami was above all an actor, not a patriarch. Therefore he embraced scholarly interpretations of Zeami in an effort to restore Zeami's spirit and rediscover that same spirit on the stage. "Every single one of Zeami's explanations," wrote Hisao, "is important for us $n \bar{o}$ actors, and I believe that he is a guiding light for anyone involved in the theatrical arts" (Kanze Hisao 2001, 29). Hisao's contribution may be his effort to actualize Zeami's ideas, but he also demonstrated how theory could inform practice-when, in the past, practice had been largely influenced by the authority stemming from the presumption of the mastery of secret knowledge. Though few performers even today may read Zeami's treatises as Hisao did, they are nevertheless more familiar with Zeami's ideas because of Hisao's work. ${ }^{8}$ In fact, the cover of the most recent collection of Hisao's essays bears the bold statement 
"a twenty-first-century Treatise on the Flower (Kadensho)," a claim that raises Hisao's ideas to the level of Zeami's own (Kanze Hisao 2001).

\section{Conclusion}

By representing Zeami's contributions, nō performers, especially those who claim to be his descendants, attempt to define $n \bar{o}$ 's traditions and their own authority over them. In fact, it has become somewhat of a cliché in performers' memoirs to compare one's own life history with Zeami's schedule for actor training described in Füshikaden. An actor might brag: "Zeami says in Füshikaden to begin training at age seven, but I made my stage debut at age four."

The three actors considered here went beyond such superficial comparisons to try to represent Zeami's legacy to a wider audience. Motoakira was one of the first performers to reconnect Zeami's theories to performance practice. He reintroduced Zeami's theories and plays to shape the ethos and structure of the Kanze school and popular conceptions of their nō. For Motoakira and his descendant Sakon, their authority as leaders of the Kanze house was inextricably linked to their blood descent from Zeami and the access to a private library of his secret writings that this link provided. Motoakira and, to a lesser degree, even Sakon lived at a time when Zeami's writings were not as widely understood, which allowed their own references to his texts to be taken as definitive even if they were sometimes erroneous. Sakon's approach-as his top disciple, Fujinami Shisetsu, described it—was to try to raise the level of audience appreciation of $n \bar{o}$ through education; Sakon said he would not lower $n \bar{o}$ to suit the audience's tastes (Fujinami 1981, 84).

Kanze Hisao would later criticize such attitudes as elitist, arguing that actors, not the audience, were the ones who needed a better understanding of their art's origins and of Zeami. In 1976 he wrote:

It has been almost seventy years since the discovery of Zeami's treatises on $n \bar{o}$. Up to a decade ago, however, they had absolutely zero influence on Japanese performing arts, especially the theatre, and they were completely ignored even in the $n \bar{o}$ world. Yet all of sudden just recently there has been what might be called a boom, and Zeami's ideas seem to be everywhere like the light of day. For example, things like Zeami's expression "never forget the beginner's mind" have entered everyday language but with their original meaning greatly distorted so that even major corporations are making catch-phrases like "return to the beginner's mind." [Kanze Hisao 2001, 26]

Hisao's interpretation of Zeami as an actor first and a patriarch a distant second threatened the institutional system that Motoakira and 
Sakon had once deployed Zeami's memory to support. That is to say: Hisao believed that reviving the spirit of Zeami would liberate $n \bar{o}$ and throw off the shackles of the conservative family-head system. Ironically, Hisao could not have taken such a revolutionary stance had he not been an important member of the Kanze house himself. Moreover, Hisao's preference for theory allows for the continued existence of the institutions he opposed-provided that these systems shift from the language of heredity and secrecy to a position of expertise founded on claims to produce and interpret genuine Zeami-based theory "authentically."

\section{NOTES}

1. "The individual calls recollections to mind by relying on the frameworks of social memory" (Halbwachs 1992, 182). The Kanze is the largest of the five schools of shite actors who perform the lead role in plays and in the chorus.

2. This is the view expressed in Kanze Motonobu's (d. 1666) Yoza Yakusha Mokuroku (Catalog of Actors of the Four Troupes) (Kanze Motonobu 1975, 29).

3. My discussion of Kanze Motoakira draws heavily on Nakamura Yasuo's seminal article $(1967,14-24)$.

4. "Performance patterns" (kata) are the repertoire of basic movements, rhythms, and vocalizations for $n \bar{o}$. "Performance pattern-added texts" (katazuke) specify the exact kata to be used in performing a given play.

5. All three of these plays were later dropped from the repertoire. It is uncertain if Zeami wrote Matsu'ura no Kagami.

6. Motoakira designated ten plays as naraimono: Sotoba Komachi (Komachi on the Gravepost) and Dōjōji, which he attributed to Kan'ami, and Higaki, Kinuta (The Fulling Board), Obasute (The Old Woman Abandoned), Sekidera Komachi (Komachi at the Sekidera Temple), Koi no Omoni (The Burden of Love), Tokusa (Scouring Rushes), Shakkyō (Stone Bridge), and Sagi (The Heron), which he attributed to Zeami (Nishio et al. 1977, 161).

7. Hisao's brother Shizuo (b. 1938) is the current Kanze Tetsunojō VIII.

8. J. Thomas Rimer notes performers' lack of interest in reading Zeami's writings (Rimer 1998, 38). When I asked my nō teacher if he read Zeami, he joked that he read only comic books (manga), but he later admitted to reading Kanze Hisao's essays.

\section{REFERENCES}

Dōmoto Masaki. 1992.

Chūsei Geinōjin no Shisō: Zeami Atosaki [The Thought of Medieval Performers: Before and After Zeami]. Tokyo: Kadokawa Shoten. 
Ejima, Ihee. 1977.

"Kanze Motoakira no Chūbon Shudōsho" [Kanze Motoakira's Annotations to Learning the Way]. In Yōkyoku, Kyogen [Nō and Kyōgen Plays]. Edited by Nishio Minoru et al. Kokugo Kokubungaku Kenkyū Shiryō Taisei [Sources and Research on Japanese Language and Literature Series], vol. 8. Tokyo: Sanshodo.

Fujinami Shisetsu. 1981.

Utai Rokujūnen: Shisetsu Oboegaki [Sixty Years of Nō Chant: The Memoirs of Shisetsu]. Tokyo: Hinoki Shoten.

Geinōshi Kenkyūkai, ed. 1978.

Kyōhō Rokunen Kakiage [Writings Presented in the Twelfth Year of the Kyōhō Era (1721)]. In Nihon Shomin Bunka Shiryō Shūsei [Collection of Records on Japanese Popular Culture], vol. 3. Tokyo: San'ichi Shobō.

Halbwachs, Maurice. 1992.

On Collective Memory. Translated by Lewis Coser. Chicago: University of Chicago Press.

Harris, Albert Joseph, Jr. 1973.

“'This Radical Noh': A Study of Two Productions by Kanze Hisao and Kanze Hideo.” Ph.D. dissertation, Ohio State University.

Kano Shigeru. 1997.

Kinsei no Nōgaku [Early Modern Nō Theatre]. Tokyo: Wan'ya Shoten.

Kanzawa Tokō. 1978.

Okinagusa [Old Man's Tales]. Nihon Zuihitsu Zenshū [Collection of Japanese Essays], vol. 21. Tokyo: Yoshikawa Kōbunkan.

Kanze Hisao. 1981.

Kanze Hisao Chosakush $\bar{u}$ [Writings by Kanze Hisao]. Vol. 2. Tokyo: Heibonsha.

. 1984.

Kokoro yori Kokoro Tsutaeru Hana [The Flower Transmitted from Mind to Mind]. Tokyo: Hakusuisha.

2001.

Kanze Hisao Zeami o Yomu [Kanze Hisao Reads Zeami]. Tokyo: Heibonsha.

Kanze Hisao et al. 1972.

"Nōgaku: Gei to Denshō" [Nō: Arts and Their Inheritance]. In Engeki Nenpyō [Japanese Theatre Annual], 87-120.

Kanze Motonobu. 1975.

Yoza Yakusha Mokuroku [Catalog of Actors of the Four Troupes]. Edited by Tanaka Makoto. Tokyo: Wan'ya Shoten.

Kanze Sakon. 1939.

Nōgaku Zuisō [Notes on Nō Theatre]. Tokyo: Kawade Shobō.

1995.

Kanzeryū Yōkyoku Hyakubansh $\bar{u}$ [One Hundred Nō Plays of the Kanze School]. Tokyo: Hinoki Shoten.

Nakamura Yasuo. 1967.

"Nō no Koteika to Iemoto Seido: Kanze Motoakira o Chūshin to shite" 
[The Standardization of Nō and the Family-Head System: The Case of Kanze Motoakira]. Geinōshi Kenkyū [Historical Research on the Performing Arts] 16:8-25.

Nishio Minoru et al. 1977.

Yōkyoku, Kyōgen [Nō and Kyōgen Plays]. In Kokugo Kokubungaku Kenkyū Shiryō Taisei [Series of Sources and Research on Japanese Language and Literature], vol. 8. Tokyo: Sanshodo.

Numa So'u. 1953.

Nōgaku Meijin no Omokage [Odes to Famous Nō Performers]. Tokyo: Hinoki Shoten.

Oda Sachiko. 1990.

"Edoki no Kanze Tayū: Kanze Motoakira no Enshutsu Kaikaku" [A Kanze Troupe Leader of the Edo Period: Kanze Motoakira's Changes in Performing]. Kokubungaku [Japanese Literature] 35(3):104-109.

Rath, Eric. 1999.

"Legends, Secrets, and Authority: Hachijō kadensho and Early Modern Noh." Monumenta Nipponica 54(2):169-194.

Rimer, J. Thomas. 1998.

"The Search for Mastery Never Ceases: Zeami's Classic Treatises on Transmitting the Traditions of the Nō Theatre." In John Singleton, ed., Learning in Likely Places: Varieties of Apprenticeship in Japan. New York: Cambridge University Press.

Sasaki Haruyuki. 1978.

Su'utai Yoyo no Ato [Traces of Unaccompanied Chant Through the Ages]. In Geinōshi Kenkyūkai, ed., Nihon Shomin Bunka Shiryō Shusei [Collection of Records on Japanese Popular Culture)], vol. 3. Tokyo: San'ichi Shōbō.

Watanabe Motoaki, ed. 1980.

Yūgen: Kanze Hisao no Sekai [Grace: The World of Kanze Hisao]. Tokyo: Libro.

Yamanaka Reiko. 1997.

"Kanze Motoakira no Kogaki o Megutte" [Concerning Kanze Motoakira's Variations]. Nōgaku Kenkyū [Nō Theatre Research] 22:125-150.

Yokomichi Mario and Kobayashi Seki. 1996.

$N \bar{o}$, Kyōgen [Nō and Kyōgen Plays]. Tokyo: Iwanami Shoten. 